\title{
Retrospective study of bacterial agents found in urine culture of dogs: antimicrobial sensitivity and resistance profile
}

\author{
Estudo retrospectivo de agentes bacterianos observados na urocultura \\ de cães: perfil de sensibilidade e resistência antimicrobiana
}

\author{
Thaís Duran Lanzi ${ }^{1}$, , Murilo Gonçalves Martins ${ }^{1 *}$ (i), Felipe Gazza Romão² (1)
}

\begin{abstract}
Urinary tract infections are commonly diagnosed in dogs, accounting for 2 to $3 \%$ of cases in the clinical routine, as cystitis being the most reported condition. Dogs of all ages and breeds can be affected, and early diagnosis is an important tool for therapeutic success. Urine culture and antibiogram are gold-standard tests for the diagnosis of bacterial cystitis, allowing correct therapy and better recovery of the patient, since currently there is great resistance to antimicrobials used in the veterinary clinics. Thus, the aim of this study was to determine the main etiological agents isolated in dog urine cultures, as well as the resistance and sensitivity profile of the isolated agents in relation to antibiotics, in order to assist the clinician's choice of the most appropriate antimicrobial, aiming at the patient's therapeutic success. For this study, a retrospective study was performed of 49 samples of urine cultures of male and female dogs, collected between 2012 and 2021, which were positive for bacterial growth. From this analysis, it was observed that Escherichia coli, Enterococcus spp. and Staphylococcus spp. were the most isolated agents, presenting higher antimicrobial resistance to cephalexin, sulfadiazine plus trimethoprim, ampicillin, enrofloxacin and ciprofloxacin, respectively.
\end{abstract}

KEYWORDS: Antibiogram; Cystitis; Escherichia coli; Urinary tract.

\begin{abstract}
RESUMO: As infecçōes do trato urinário são comumente diagnosticadas em cães, representando de 2 a 3\% dos casos na rotina clínica, sendo a cistite a afecçáo mais relatada. Cáes de todas as idades e raças podem ser acometidos, sendo o diagnóstico precoce uma ferramenta importante para o sucesso terapêutico. A urocultura e o antibiograma são exames padrão-ouro para o diagnóstico das cistites bacterianas, permitindo a terapêutica correta e melhor recuperação do paciente, já que atualmente há grande resistência aos antimicrobianos empregados na rotina clínica veterinária. Desta forma, o objetivo deste estudo foi determinar os principais agentes etiológicos isolados nas uroculturas de cães, bem como o perfil de resistência e sensibilidade dos agentes isolados frente aos antibióticos, de modo a auxiliar o médico veterinário na eleição do antimicrobiano mais adequado, visando sucesso terapêutico do paciente. Para realizaçáo deste estudo foi feita uma análise retrospectiva de 49 uroculturas de cáes machos e fêmeas, coletadas entre os anos de 2012 e 2021, as quais apresentaram crescimento bacteriano positivo. A partir desta análise foi observado que Escherichia coli, Enterococcus spp. e Staphylococcus spp. foram os agentes mais isolados nas uroculturas, apresentando maior resistência aos antimicrobianos cefalexina, sulfazotrim ampicilina, enrofloxacina e ciprofloxacina, respectivamente.
\end{abstract}

PALAVRAS-CHAVE: Antibiograma; Cistite; Escherichia coli; Trato urinário.

\section{INTRODUCTION}

Urinary tract infections (UTI) are common causes attending veterinary clinical care, and dogs are more affected than felines (OLIVEIRA et al. 2019; SORENSEN et al., 2019; HERNANDO et al., 2021). Urinary tract portions are usually considered sterile, except for the distal urethra that has its own microbiota. When one of these segments is affected, ITUs appear, that is, there is colonization by microorganisms that can affect the kidneys, ureters, bladder or urethra (KOGIKA; WAKI, 2015).

About $14 \%$ of dogs are affected by bacterial infections of the urinary tract at some point in their life, without age or breed predilection; however, spayed females and elderly animals are most affected, with a mean age of 7 to 8 years (ÇETIN et al., 2003; WONG; EPSTEIN; WESTROPP, 2015). Clinical signs may vary according to the affected part of the urinary tract, 
extent and severity of the lesion, microorganism involved and defense mechanism's activity (BYRON, 2019).

Bacterial cystitis is the lower urinary tract disease that is most prevalent in dogs, accounting for $40 \%$ of cases, followed by urinary incontinence and urolithiasis (BARSANTI, 2006). It is characterized by inflammation and/or infection of the urinary bladder, which may cause signs such as hematuria, pollakiuria and dysuria, although some animals may be asymptomatic (RIBEIRO, 2011). Most infections occur due to bacteria ascending from the distal urethra, accounting for $95 \%$ of cases, or from gastrointestinal tract and dermal origin (BARSANTI, 2006; KOGIKA; WAKI, 2015). The guidelines of the International Society for Companion Animal Infectious Diseases (ISCAID), published in 2019, classifies this condition as sporadic bacterial cystitis, recurrent, and subclinical bacteriuria (WEESE, et al. 2019).

Among the main diagnostic methods of this condition, urinalysis has been shown to be a starting point for diagnostic confirmation, by assessing parameters such as urine specific gravity, composition of urine and especially the evaluation of urinary sediment; this information enable the identification of ITUs and the presence or not of bacterial interactions; however, quantitative urine culture and antibiogram become essential tests in order to identify the causative agent of UTI for subsequent appropriate antibiotic therapy. The most isolated agents are: Escherichia coli, Proteus spp., Pseudomonas spp., Salmonella spp., Staphylococcus spp., Streptococcus spp. and Enterococcus spp. (BYRON, 2019; OLIVEIRA et al., 2019). Currently, there is a major problem regarding the use of antibiotics in the treatment of cystitis; due to their indiscriminate use, there is the emergence of increasingly resistant bacterial strains. This is an aggravating factor when the concept of one health is addressed, as it directly implies therapeutic failures (RIBEIRO, 2011; PUNIA et al., 2018).

Thus, the aim of this retrospective study was to evaluate the sensitivity of microorganisms involved in bacterial cystitis to most used antibiotics in dogs, based on the results of urine culture and antibiogram, in order to play a role to the academic and veterinary community, regarding a more appropriate and effective antibiotic therapy against the agent identified in urine culture and antibiogram tests.

\section{MATERIALS AND METHODS}

A retrospective study was carried out, based on the database of two veterinary laboratories (Proanalysi and EDAN), located in the city of Bauru, state of São Paulo. We analyzed 49 urine samples from dogs with suspected urinary tract infection, which were referred for urine culture and antibiogram between 2012 and 2021.

For urine sampling, the animals were submitted to trichotomy of the abdominal region, undergoing antisepsis of the site for needle insertion with alcohol $70 \%$, which was properly guided by ultrasound. The collection was then performed with a disposable $10-\mathrm{mL}$ syringe and a $25 \mathrm{~mm} \times 7 \mathrm{~mm}$ needle, and the samples were sent immediately to the laboratory. The collection was performed in the presence of the owner, who assisted in the restraint, and the sonographer. The samples were stored $\left(2-6^{\circ} \mathrm{C}\right)$ and inoculated within the maximum period of 3 hours in blood agar and MacConkey agar (Figure 1).

The included samples were collected by cystocentesis and processed in the laboratory. Bacterial isolation and antibiogram profile pursued laboratory standards. Cultures were performed with fresh samples, in blood and MacConkey agar plates, and not "in house" plates, using platinum loop for inoculation. For the antibiogram (Figure 2), sterile injection water was used in a sterile Falcon tube. The CFU/mL count was not performed.

Sixteen antibiotics were tested in the antibiogram profile, among them: amoxicillin plus clavulanate, ampicillin, cephalexin, cefovecin, ceftiofur, ceftriaxone, ciprofloxacin, chloramphenicol, doxycycline, enrofloxacin, gentamycin, mupirocin, neomycin, oxacillin, polymyxin and sulfadiazine plus trimethoprim.

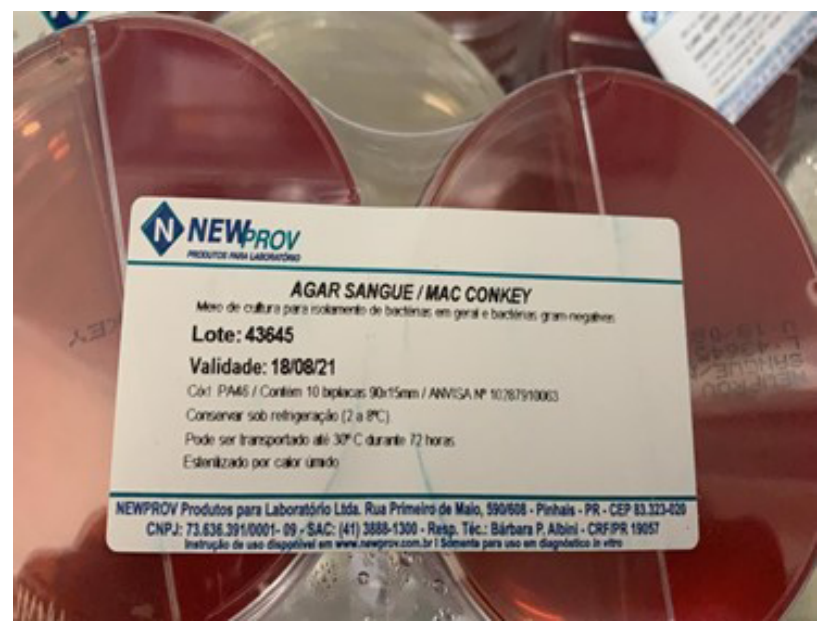

Figure 1. Blood agar plates used for urine cultures.

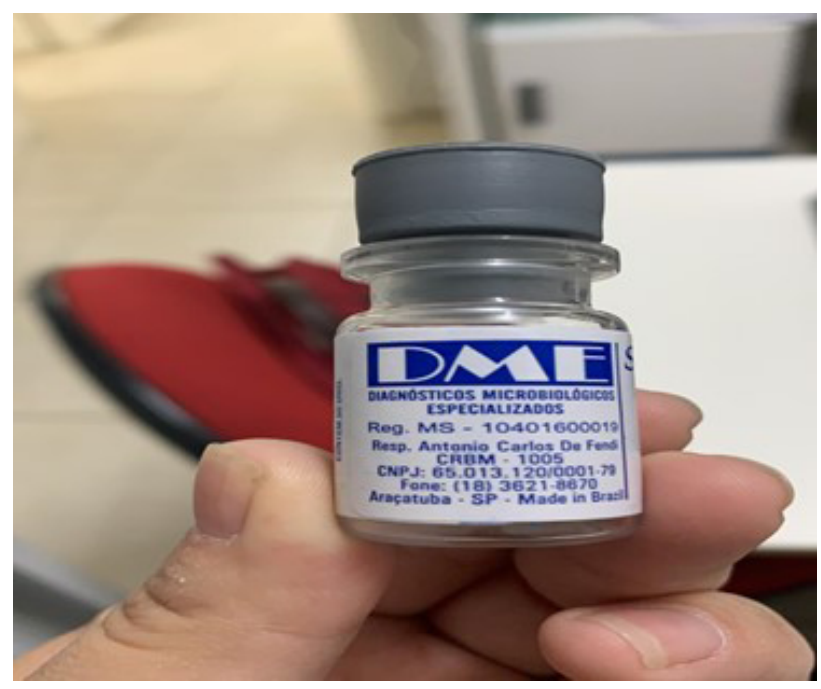

Figure 2. Antibiogram vial used during the examinations. 
The data presented in this research correspond to a group of dogs, including males and females, spayed or not, from several breeds, which showed positive results on urine culture test. Unfortunately, as the materials provided are limited only to urine cultures and antibiograms without the clinical analysis of animals, it was not possible to classify cystitis according to ISCAID. The study focused on isolated agents and their interactions with the treatments employed.

\section{RESULTS AND DISCUSSION}

We observed 49 samples that had positive bacterial growth. From the gender analysis (males and females), it was found

Table 1. Age group and number of male and female dogs, which showed bacterial growth in the urine culture test

\begin{tabular}{l|c|c|c} 
Age & Females (\%) & Males (\%) & Total \\
$\begin{array}{l}\text { Puppies (0-1 } \\
\text { year old) }\end{array}$ & - & $2(11,11 \%)$ & $2(5,26 \%)$ \\
\hline $\begin{array}{l}\text { Adult (1-8 } \\
\text { years old) }\end{array}$ & $4(20 \%)$ & $5(27,78 \%)$ & $9(23,68 \%)$ \\
\hline $\begin{array}{l}\text { Elderly (>8 } \\
\text { years old) }\end{array}$ & $16(80 \%)$ & $11(61,11 \%)$ & $27(71,05 \%)$ \\
\hline Total (100\%) & 20 & 18 & 38 \\
\hline
\end{tabular}

*The age of some animals was not informed in the exam request. that Escherichia coli was the most isolated agent, accounting for $38.77 \%$ of the positive samples, followed by Staphylococcus spp. (18.36\%) and Enterococcus spp. (10,20\%). Other pathogens were isolated, but with lower percentages.

Table 1 shows the quantitative values of males and females used in this study, including age group, as adults and elderly patients obtained an approximate percentage, suggesting higher prevalence in these groups.

Regarding the most isolated pathogen in each group (males and females), it was found that Enterococcus spp., Escherichia coli and Staphylococcus spp. were the most isolated in females, while in the group of males, the most prevalent were Escherichia coli, Klebsiella spp. and Citrobacter spp., as shown in tables 2 and 3.

In relation to the most affected breeds, this study reveals that mongrel dogs were the most affected, followed by Lhasa apso, Yorkshire terrier, Shih tzu and Poodle, as shown in table 4.

Regarding the antimicrobials tested in this study, higher rates of sensitivity and resistance were observed for amoxicillin plus clavulanate and cephalexin, respectively. Such data are represented in tables 5 and 6 , which demonstrate the percentage of sensitivity and resistance of the three main etiological agents found in the urine cultures analyzed.

It is important to highlight that the differences in the percentage values between etiological agents occurred due to the fact that some samples were not tested for certain antimicrobials.

Table 2. Agents isolated on urine samples of bitches between 0 and 16 years old

\begin{tabular}{l|c|c|c|c}
\hline Agent & Puppy (0-1 year old) & Adult (1-8 years old) & Elderly (>8 years old) & Total (\%) \\
\hline Enterococcus spp. & -- & 1 & 3 & $4(21,05 \%)$ \\
\hline Escherichia coli & -- & 1 & 4 & $5(26,32 \%)$ \\
\hline Staphylococcus spp. & -- & 1 & 4 & $5(26,32 \%)$ \\
\hline Pseudomonas spp. & -- & -- & 1 & $1(5,26 \%)$ \\
\hline Streptococcus spp. & -- & -- & 1 & $1(5,26 \%)$ \\
\hline Klebsiella spp. & -- & -- & 1 & $1(5,26 \%)$ \\
\hline Proteus mirablis & -- & 1 & 15 & $2(10,53)$ \\
\hline Total & 0 & 4 & $19(100 \%)$ \\
\hline
\end{tabular}

*The age of some animals was not informed in the exam request.

Table 3. Isolated agents of urine from male dogs with 0 to 17 years old

\begin{tabular}{l|c|c|c|c}
\hline Agent & Puppy (0-1 year old) & Adult (1-8 years old) & Elderly (>8 years old) & Total (\%) \\
\hline Escherichia coli & 2 & 2 & 5 & $9(50 \%)$ \\
\hline Staphylococcus spp. & -- & -- & 1 & $1(5,56 \%)$ \\
\hline Klebsiella spp. & -- & 3 & 1 & $4(22,22 \%)$ \\
\hline Enterobacter & -- & 1 & -- & $1(5,56 \%)$ \\
\hline Enterococcus spp. & -- & -- & -1 & $1(5,56 \%)$ \\
\hline Proteus mirablis & -- & -- & 2 & 0 \\
\hline Citrobacter spp. & -- & -- & 10 & $2(11,10 \%)$ \\
\hline Total & 2 & 6 & $18(100 \%)$ \\
\hline
\end{tabular}

*The age of some animals was not informed in the exam request. 
According to Hariharan et al. (2016), approximately $75 \%$ of cases of UTIs in dogs are caused by the presence of a sole pathogen. This statement can also be confirmed in this study, as 48/49 (97.96\%) samples involved only one etiological agent, and only $1 / 49$ (2.04\%) sample had two agents involved.

Table 4. Breeds of dogs affected by urinary tract infections from the analysis of urine cultures

\begin{tabular}{l|c|c|c} 
Breed & Females & Males & Total (\%) \\
\hline Mongrel dogs & 10 & 4 & $14(28,57 \%)$ \\
\hline Lhasa apso & 3 & 4 & $7(14,29 \%)$ \\
\hline Yorkshire terrier & 3 & 5 & $8(16,33 \%)$ \\
\hline Shih tzu & 2 & 3 & $5(10,20 \%)$ \\
\hline Poodle & 5 & -- & $5(10,20 \%)$ \\
\hline Golden retriever & 1 & -- & $1(2,04 \%)$ \\
\hline Pinscher & -- & 1 & $1(2,04 \%)$ \\
\hline Border collie & 1 & -- & $1(2,04 \%)$ \\
\hline Saint Bernard & -- & 1 & $1(2,04 \%)$ \\
\hline Schnauzer & 1 & -- & $1(2,04 \%)$ \\
\hline Basset hound & -- & 1 & $1(2,04 \%)$ \\
\hline Boxer & 1 & -- & $1(2,04 \%)$ \\
\hline Dalmatian & -- & 1 & $1(2,04 \%)$ \\
\hline Labrador retrievers & 1 & 1 & $2(4,09 \%)$ \\
\hline Total & 26 & 33 & $49(100 \%)$ \\
\hline
\end{tabular}

*Difference between number of males and females in relation to the number of isolated agents occurs due to the isolation of more than one pathogen in some samples.
As described by Santos et al. (2005), Siqueira et al. (2008), Carvalho et al. (2014) and Byron (2019), 75\% of UTI's cases have gram-negative bacteria as etiological agents, as Escherichia coli being the most commonly isolated, followed by Proteus spp., Klebsiella spp., Pseudomonas spp. and Enterobacter spp. The most isolated gram-positive bacteria include: Staphylococcus spp., Streptococcus spp. and Enterococcus spp. Of the cultures analyzed in this study, we found a higher prevalence of gramnegative bacteria Escherichia coli in males, accounting for 50\% of the samples, a fact also observed by Hernando et al. (2021), followed by Klebsiella spp. and Citrobacter spp. This distribution, also observed by Wong, Epstein and Westropp (2015), can be explained by the resistance mechanisms presented by these bacteria, already known.

In females, there was higher prevalence of the bacteria Escherichia coli and Staphylococcus spp. (26.32\%), followed by Enterococcus spp. Monteiro and Pereira (2013) describe that the same etiological agents found in this study are part of the distal urethra flora, both in male dogs and in females, so it is suggested that the infection is ascending, considering that one of the main routes of infection is by the distal urethra.

From the analysis of urine cultures, it was found that females were most affected by urinary tract infections, accounting for $52.63 \%$ of positive results, while males represented $47.36 \%$ of the samples. As described by Kogika and Waki (2015), and Sorensen et al. (2019), the diagnosis of ITU in females is relatively common due to the proximity of the genitourinary region to the anus region, considering that the main source of infection occurs through bacteria of urethral and intestinal

Table 5. Percentage of antimicrobial sensitivity of samples of the main etiological agents found in dog urine cultures.

\begin{tabular}{l|c|c|c|c}
\hline Antimicrobial & Escherichia coli (\%) & Enterococcus spp. (\%) & Staphylococcus spp. (\%) & $\begin{array}{c}\text { Total of sensitive } \\
\text { samples (\%) }\end{array}$ \\
\hline Amoxicillin + clavulanate & $90 \%(18 / 20)$ & $100 \%(5 / 5)$ & $77,78 \%(7 / 9)$ & $88,23 \%(30 / 34)$ \\
\hline Ampicillin & $25 \%(5 / 20)$ & $100 \%(5 / 5)$ & $44,44 \%(4 / 9)$ & $41,18 \%(14 / 34)$ \\
\hline Cephalexin & $50 \%(10 / 20)$ & $20 \%(1 / 5)$ & $55,56 \%(5 / 9)$ & $47,06 \%(16 / 34)$ \\
\hline Cefovecin & $35 \%(7 / 20)$ & $20 \%(1 / 5)$ & $33,33 \%(3 / 9)$ & $32,35 \%(11 / 34)$ \\
\hline Ceftiofur & $55 \%(11 / 20)$ & $40 \%(2 / 5)$ & $55,56 \%(5 / 9)$ & $52,94 \%(18 / 34)$ \\
\hline Ceftriaxone & $50 \%(10 / 20)$ & $20 \%(1 / 5)$ & $77,78 \%(7 / 9)$ & $52,94 \%(18 / 34)$ \\
\hline Ciprofloxacin & $55 \%(11 / 20)$ & $80 \%(4 / 5)$ & $66,67 \%(6 / 9)$ & $61,76 \%(21 / 34)$ \\
\hline Chloramphenicol & $70 \%(14 / 20)$ & $80 \%(4 / 5)$ & $55,56 \%(5 / 9)$ & $67,65 \%(23 / 34)$ \\
\hline Doxycycline & $20 \%(4 / 20)$ & $80 \%(4 / 5)$ & $22,22 \%(2 / 9)$ & $29,41 \%(10 / 34)$ \\
\hline Enrofloxacin & $55 \%(11 / 20)$ & $80 \%(4 / 5)$ & $77,78 \%(7 / 9)$ & $64,71 \%(22 / 34)$ \\
\hline Gentamicin & $70 \%(14 / 20)$ & $20 \%(1 / 5)$ & $88,89 \%(8 / 9)$ & $67,65 \%(23 / 34)$ \\
\hline Mupirocin & & $11,11 \%(1 / 9)$ & $2,94 \%(1 / 34)$ \\
\hline Neomycin & $10 \%(2 / 20)$ & $11,11 \%(1 / 9)$ & $8,82 \%(3 / 34)$ \\
\hline Oxacillin & & $11,11 \%(1 / 9)$ & $2,94 \%(1 / 34)$ \\
\hline Polymyxin & $10 \%(2 / 20)$ & $11,11 \%(1 / 9)$ & $8,82 \%(3 / 34)$ \\
\hline Sulfadiazine plus trimethoprim & $25 \%(5 / 20)$ & $40 \%(2 / 5)$ & $55,56 \%(5 / 9)$ & $35,29 \%(12 / 34)$ \\
\hline
\end{tabular}


Table 6. Percentage of antimicrobial resistance of samples of the main etiological agents found in dog urine cultures.

\begin{tabular}{l|c|c|c|c}
\hline Antimicrobial & Escherichia coli (\%) & Enterococcus spp. (\%) & $\begin{array}{c}\text { Staphylococcus spp. (\%) } \\
\text { Total of resistant } \\
\text { samples (\%) }\end{array}$ \\
\hline Amoxicillin+ clavulanate & $10 \%(2 / 20)$ & & $22,22 \%(2 / 9)$ & $11,76 \%(4 / 34)$ \\
\hline Ampicillin & $55 \%(11 / 20)$ & & $11,11 \%(1 / 9)$ & $35,29 \%(12 / 34)$ \\
\hline Cephalexin & $50 \%(10 / 20)$ & $80 \%(4 / 5)$ & $53,33 \%(3 / 9)$ & $32,35 \%(11 / 34)$ \\
\hline Cefovecin & $35 \%(7 / 20)$ & $80 \%(4 / 5)$ & $26,47 \%(9 / 34)$ \\
\hline Ceftiofur & $30 \%(6 / 20)$ & $60 \%(3 / 5)$ & $26,47 \%(9 / 34)$ \\
\hline Ceftriaxone & $40 \%(8 / 20)$ & $20 \%(1 / 5)$ & $35,29 \%(12 / 34)$ \\
\hline Ciprofloxacin & $45 \%(9 / 20)$ & $20 \%(1 / 5)$ & $22,22 \%(2 / 9)$ & $26,47 \%(9 / 34)$ \\
\hline Chloramphenicol & $25 \%(5 / 20)$ & $20 \%(1 / 5)$ & $33,33 \%(3 / 9)$ & $26,47 \%(9 / 34)$ \\
\hline Doxycycline & $45 \%(9 / 20)$ & & & $35,29 \%(12 / 34)$ \\
\hline Enrofloxacin & $45 \%(9 / 20)$ & $20 \%(1 / 5)$ & $22,22 \%(2 / 9)$ & $29,41 \%(10 / 34)$ \\
\hline Gentamicin & $25 \%(5 / 20)$ & $80 \%(4 / 5)$ & $11,11 \%(1 / 9)$ & $14,71 \%(5 / 34)$ \\
\hline Mupirocin & $10 \%(2 / 20)$ & $60 \%(3 / 5)$ & & $8,82 \%(3 / 34)$ \\
\hline Neomycin & & $60 \%(3 / 5)$ & & $14,71 \%(5 / 34)$ \\
\hline Oxacillin & $10 \%(2 / 20)$ & $60 \%(3 / 5)$ & & $8,82 \%(3 / 34)$ \\
\hline Polymyxin & & $60 \%(3 / 5)$ & & $47,06 \%(16 / 34)$ \\
\hline Sulfadiazine plus trimethoprim & $65 \%(13 / 20)$ & & & \\
\hline & & & & \\
\hline
\end{tabular}

origin, both in males and females. In addition, the urethra of females is shorter when compared to males, which makes it easier to the pathogens to ascend in the urinary tract. Studies reveal that spayed females become more predisposed to UTIs due to estrogen hormone deficiency, which can cause functional failure in the internal urethral sphincter and subsequent urinary incontinence, causing these females to become more exposed to infections (MENDÓZA-LÓPEZ et al., 2017).

Regarding the age of the affected animals, Mendóza-López et al. (2017) describes that the animals most affected by ITUs have an mean age of 8 years old, because usually elderly animals have concomitant diseases, which can alter the mechanisms of defense of the urinary tract, making them more susceptible to infections. The present study showed that there was an similar percentage between the groups of adults and the elderly patients, suggesting greater involvement in these groups.

According to Ferreira et al. (2014) the most predisposed breeds are: Cocker spaniel, Poodle, Yorkshire terrier, Labrador retriever and mongrel dogs. Mendóza-López et al. (2017) state that mongrel dogs are most affected due to their mixture of predisposed breeds. In this study, the most affected animals were the mongrel dogs, totaling $28.57 \%$ of the samples. These variations can be caused by physiological and/or anatomical differences between breeds and by the fact that mongrel dogs being the most represented in these studies.

Among all the samples submitted to the antibiogram, it is noted that sulfadiazine plus trimethoprim followed by cephalexin recorded the highest rates of resistance to pathogens identified. During the research, there was a rate of $47.06 \%$ of general resistance to the use of sulfadiazine plus trimethoprim, and up to $65 \%$ when evaluated against isolates of Escherichia coli. According to Spinosa, Górniak and Bernardi (2017), sulfamides were one of the first antimicrobials effective in systemic treatments of bacterial infections, being widely used in humans and animals, emerging up to 5000 similar substances from studies of the following decade; however, of these, only 20 proved effective for treatments, also used as chemotherapy. This group is falling in disuse because of increasing rates of resistance; its use was only reconsidered with the discovery of the association with trimethoprim, that potentiates its effectiveness in bacterial infections. Bacterial resistance to sulfamides usually occurs gradually and slowly, but once established is irreversible, which occurs mainly due to plasmid and as a consequence of recurrent use; thus, the inefficacy demonstrated in this study may be due to years of use of this drug, which is even used preventively mainly in confined regimes, favoring the development of new cases of resistance (SPINOSA; GÓRNIAK; BERNARDI, 2017).

As also reported by Wong, Epstein and Westropp (2015), the findings observed reinforce the need to use tests such as urine culture, in order to minimize possible effects of resistance of microorganisms to antibiotics, directing treatment whenever possible based on these results. In this study, it was observed that the highest sensitivity rates were achieved by amoxicillin plus clavulanate, which agrees with the results of Wong, Epstein and Westropp (2015). Other drugs that, although inferior, were also effective in the study, such as chloramphenicol, had this result due to their broad-spectrum characteristics, having great action against gram-negative bacteria, such as Escherichia coli, and gram-positive as the 
pathogens Staphylococcus spp. and Enterococcus spp. (SPINOSA; GÓRNIAK; BERNARDI, 2017).

It was observed that most bacteria have been shown to be sensitive to gentamicin, which can be explained by most of them being aerobic, more sensitive to the use of aminoglycosides due to their mechanism of action. Enrofloxacin, a second-generation fluoroquinolone, which according to Spinosa, Górniak and Bernardi (2017) has greater indications for Enterobacteria and Pseudomonas Aeruginosa, but only the latter was observed during the research; however, it was also found great sensitivity to other agents during the study, perhaps due to the characteristics that differ this antibiotic from the first generation of its class, since anaerobic and grampositive bacteria were the most prevalent pathogens isolated, yielding good results (SPINOSA, 2017).

In a study by Siqueira et al. (2008), as well as in this study, it was observed that the strains of bacteria found in dogs with cystitis showed greater resistance to sulfonamides, tetracyclines and some cephalosporins, such as cephalexin, that has low sensitivity against Enterococcus spp. , a very prevalent bacteria; however, good sensitivity to fluoroquinolone and ampicillin was also observed by Siqueira et al. (2008), data that partially contradict the results of this study, since ampicillin proved to be very inefficient during the research, although it is very similar to amoxicillin regarding the mode of action and chemical structure. Ampicillin is the first broadspectrum penicillin introduced in therapeutic protocols, thus generating a lot of bacterial resistance to this drug (SPINOSA; GÓRNIAK; BERNARDI, 2017).

In the study by Ferreira et al. (2014), higher resistance rates were observed against sulfadiazine plus trimethoprim and enrofloxacin, what can also be observed during the study, since most isolates belong to gram-negative pathogens that are not sensitive to fluoroquinolones. Regarding amoxicillin with clavulanate, good results were obtained because it has a broad spectrum, excellent performance in the urinary tract and it is potentialized when associated with clavulanate.

Regarding the performance of gentamicin and cephalexin, the results demonstrate an action that can be considered median, and gentamicin is superior to cephalexin due to the majority of isolates belonging to aerobic bacteria, precisely the spectrum whose action of the aminoglycosides is better (SPINOSA; GÓRNIAK; BERNARDI, 2017). These facts indicate that the sensitivity and resistance profile of microorganisms varies according to the studied region and period, which provides even more subsidies for the realization of urine culture and antibiogram for the direction of therapy.

Regarding Escherichia coli isolates, the most prevalent microorganism in cases of UTIs, according to Çetin et al. (2003), also demonstrates that the most effective antimicrobials for this agent was amoxicillin plus clavulanate, chloramphenicol and gentamicin, due to their characteristics and spectra of action. According to Punia et al. (2018), it was observed that the lowest sensitivity of this pathogen was to ampicillin because it is an antibiotic that has already being used for a long time, being one of the first broad-spectrum penicillin in use, which is partially proven in the study, in which ampicillin is among the lowest rates of effective antibiotics (25\%). Neomycin and polymyxin presented even lower values, obtaining positive results in only $10 \%$ of the samples.

Therefore, it is noted that each study reveals different antibiogram profiles. This fact can be explained by differences in microbial sensitivity and resistance profiles, geographic differences and variable efficacy of different antimicrobials. It is important to highlight that one of the limiting factors of the study involves the lack of more accurate information in the requests, such as the patient's clinical history, and even, in many, the suspicion of the veterinarian clinician, which impairs the evaluation by the study. In general, the data reinforce the idea of instituting urine culture and antibiogram guided-treatment.

\section{CONCLUSIONS}

Lower urinary tract infections are common in veterinary clinics, with cystitis being the most prevalent condition. Urine culture followed by an antibiogram are extremely important tests for a correct diagnosis of UTIs, since it is possible to determine the etiological agent involved, as well as to assist in the choice of the most appropriate therapy for each patient. In general, among the isolated agents, Escherichia coli was the most prevalent. It is important to emphasize that multidrug-resistant bacterial strains are already a reality in veterinary medicine; therefore, the choice of the most appropriate antimicrobial decreases the probability of error, which in turn decreases the frequency of therapies and makes them more effective. Thus, these factors contribute to a faster recovery of the patient, reducing antimicrobial resistance rates.

\section{REFERENCES}

BARSANTI, J. A. Genitourinary infections. In: GREENE, C. E. Infectious diseases of the dog and cat. 3.ed. St Louis, Missouri: Saunders/ Elsevier, 2006. cap. 91, p. 1888-1953.

BYRON, J. K. Urinary tract infection. The Veterinary Clinics of North America: Small Animal Practice, v. 49, n. 2, p. 2ll221, 2019.
CARVALHO, V. M. et al. Infecções do trato urinário (ITU) de cães e gatos: etiologia e resistência aos antimicrobianos. Pesquisa Veterinária Brasileira, São Paulo, v. 34, n. 1, p. 62-70, 2014.

ÇETIN, C. et al. Bacteriological Examination of Urine Samples from Dogs with Symptoms of Urinary Tract Infection. Turkish Journal of Veterinary and Animal Sciences, v. 27, n. 5, p. 1225-1229, 2003. 
FERREIRA, M. C. et al. Agentes bacterianos isolados de cães e gatos com infecção urinária: perfil de sensibilidade aos antimicrobianos. Atas de saúde ambiental, v. 2, п. 2, p. 30-37, 2014.

HARIHARAN, H. et al. Bacterial Isolates from Urinary Tract Infection in Dogs in Grenada, and Their Antibiotic Susceptibility. Open Journal of Veterinary Medicine, v. 6, p. 85-88, 2016.

KOGIKA, M. M.; WAKI, M. F. Infecção do trato urinário inferior. In: JERICÓ, M. M.; NETO, J. P. A.; KOGIKA, M. M. Tratado de medicina interna de cães e gatos. 2 . ed. Rio de Janeiro: Roca, 2015. p. 4399-4489.

MENDÓZA-LÓPEZ, C. I. et al. Analysis of lower urinary tract disease of dogs. Pesquisa Veterinária Brasileira, v. 37, n. 1l, p. 1275-1280, 2017.

MONTEIRO, M.; PEREIRA, H. Caracterização das infeções do trato urinário de origem microbiana - casuística de um hospital veterinário em Lisboa. Revista Lusófona de Ciência e Medicina Veterinária, v. 6, p. 1-23, 2013.

OLIVEIRA, R. P. et al. Cistite canina causada por Salmonella enterica subsp. entérica. Acta Scientiae Veterinariae, v. 47, n. 1, 2019.

PUNIA, M. et al. Pathogens isolated from clinical cases of urinary tract infection in dogs and their antibiogram. Veterinary World, v. 1l, n. 8, p. 1037-1042, 2018.
RIBEIRO, N. A. S. Infecção do trato urinário inferior em cães. Revista de Educação Continuada em Medicina Veterinária e Zootecnia do CRMV-SP, v. 9, n. 1, p. 38-41, 2011.

SANTOS, M. R. et al. Suscetibilidade a antimicrobianos, de bactérias isoladas de diversas patologias em cães e gatos, nos anos de 2002 e 2003. Veterinária em foco, v. 2, n. 2, p. 157-164, 2005.

SIQUEIRA, A. K. et al. Perfil de sensibilidade e multirresistência em linhagens de Escherichia coli isoladas de infecção do trato urinário, de piometra e de fezes de cães. Arquivo Brasileiro de Medicina Veterinária e Zootecnia, v. 60, n. 5, p. 1263-1266, 2008.

SORENSEN, T.M. et al. Pre-test probability of urinary tract infection in dogs with clinical signs of lower urinary tract disease. The Veterinary Journal, v. 247, p.65-70, 2019.

SPINOSA, H. S.; GÓRNIAK, S. L.; BERNARDI, M. M. Farmacologia Aplicada à Medicina Veterinária. 6. ed. Rio de Janeiro: Guanabara Koogan, 2017. 1420p.

WEESE, J. S. et al. International Society for Companion Animal Infectious Diseases (ISCAID) guidelines for the diagnosis and management of bacterial urinary tract infections in dogs and cats. The Veterinary Journal, v. 247, p. 8-25, 2019

WONG, C.; EPSTEIN, S. E.;WESTROPP, J.L.Antimicrobial Susceptibility Patterns in Urinary Tract Infections in Dogs (2010-2013). Journal of Veterinary Internal Medicine, v. 29, n. 4, p. 1045-1052, 2015. 